\title{
UNTANGLING THE MAZE OF EUROPEAN UNION FUNDS TO BULGARIA
}

\author{
by Gallina Andronova Vincelette and Iglika Vassileva,
}

The World Bank

\begin{abstract}
The paper presents a fiscal estimate of Bulgaria's perspective European Union (EU) membership. The projected EU funds have two distinct effects: first, there is the overall effect on the balance of payments of the country; and second, there is the pure effect on the national budget. The paper concludes that the country is likely to benefit from large net inflows of resources of an average of $3.7 \%$ of gross domestic product (GDP) in 2007-2009. In contrast, Bulgaria's fiscal position is expected to deteriorate by $1.6 \%$ of GDP on average in 2007-2009, if no expenditure restructuring of the fiscal framework is carried out. The expected deterioration of the public finances related to EU accession would be due to co-financing requirements, national contributions to the EU budget, and possible full pre-financing of the EU direct payments to Bulgarian farmers in the first year of accession. However, the above expenditures will be partly offset by the budgetary compensation allocated out of the EU budget, savings from agricultural subsidies and shifting of certain public expenditures to Cohesion Fund-supported projects.
\end{abstract}

\section{World Bank Policy Research Working Paper 3962, July 2006}

The Policy Research Working Paper Series disseminates the findings of work in progress to encourage the exchange of ideas about development issues. An objective of the series is to get the findings out quickly, even if the presentations are less than fully polished. The papers carry the names of the authors and should be cited accordingly. The findings, interpretations, and conclusions expressed in this paper are entirely those of the authors. They do not necessarily represent the view of the World Bank, its Executive Directors, or the countries they represent. Policy Research Working Papers are available online at http://econ.worldbank.org.

We thank Peter Miovic, Satu Kristiina Kahkonen, Bernard Funck, Martin Hallet, Yasemin Bal Gunduz among others for their suggestions and comments on an earlier version of the paper. All data files available upon request from the authors. Authors can be reached at gvincelette@worldbank.org and iglikav@gmail.com. 


\section{A. INTRODUCTION}

European Union (EU) membership allows new member states (NMS) to fully benefit from sizeable EU transfers to national budgets, among other things. Given the lower standard of living in Bulgaria, the Union has committed a considerable amount of assistance to the country after its suggested accession in 2007. The aim of these transfers is to facilitate Bulgaria's income convergence with the rest of the EU. However, EU membership is also associated with member states' contributions to the EU budget, while complying to the 2002 Copenhagen summit principle of maintaining pre-accession net fiscal positions after joining the EU. ${ }^{1}$ Inevitably, EU accession brings new fiscal challenges to the NMSs' national budgets, as resources enter into and exit from the new members' national budget accounts. Hence, a key question for prospective EU members is whether, on balance, membership would engender positive effects or instead bring about fiscal strains for the new member country.

This paper presents a fiscal estimate of the prospective EU membership of Bulgaria. The projected EU funds have two distinct effects: first, there is the overall effect on the balance of payments of the country; and second, there is the pure effect on the national budget. The paper concludes that the country is likely to benefit from large net inflows of resources of an average of $3.7 \%$ of gross domestic product (GDP) in 2007-2009. In contrast, Bulgaria's fiscal position is expected to deteriorate by $1.6 \%$ of GDP on average in 2007-2009, if no expenditure restructuring of the fiscal framework is carried out.

EU accession is expected to bring about additional direct and indirect effects on the revenue side of the budget, owing to the alignment of the national legislation with the acquis communautaire and second-round positive impacts of EU accession on trade integration, investment and growth. However in this paper, only the direct effects on the budget have been estimated. Additionally, the impact on the budget balance is calculated on a cash basis, assuming that all EU related public expenditures would be recorded in the consolidated fiscal program. The estimates are based on the official Financial Package for the Accession Negotiation of Bulgaria and Romania of 2004 and updated with information from the Accession Treaty for Bulgaria and Romania. We also rely on the latest available information and data obtained from the national authorities in Bulgaria and the EU. Finally, the changes envisaged for the 2007-2013 financial perspective regarding EU funds' attribution and co-financing rates have also been taken into account.

The paper is structured as follows. The next section B briefly outlines the financial envelope for Bulgaria. Based on this negotiated financial framework, section $C$ analyzes the overall net impact of EU accession for Bulgaria and traces all flows between Bulgaria and the European Union. It describes the inflows to the country: various payments appropriations from the EU budget as well as pre-accession instruments (under which disbursements might continue until 2011). The outflows of funds from Bulgaria, namely the Bulgarian contribution to the EU budget are also treated in this section. In the next section D, the direct net effect on the national budget for 20072009 is estimated and compared to the overall effect on Bulgaria's balance of payments. In both estimates, we employ a cash-flow approach as opposed to an accrual budget accounting in order to gauge the macroeconomic implications on the budget. Section $E$ summarizes the macroeconomic and absorption challenges which Bulgaria’s EU accession brings.

1 See The Presidency Conclusions of the Copenhagen Summit of December 2002, at http://ue.eu.int/ueDocs/cms_Data/docs/pressData/en/ec/73842.pdf 


\section{B. OUTLINE OF THE FINANCIAL ENVELOPE}

The EU has committed $€ 4.6$ bn in 2004 prices in commitment appropriations to Bulgaria for the period 2007-2009, as presented in Table $1 .^{2}$ The financial envelope is based on the Financial Package for Bulgaria and Romania, published in a European Commission Communication of February 10, 2004 and updated in the rural development allocations part. ${ }^{3}$ Committed resources to Bulgaria are classified in three categories: policy-oriented expenditures; administrative expenditures; and budget compensation. Resources for Structural Actions for the first three years of accession comprise almost a half of EU commitments to Bulgaria, while resources for Common Agricultural Policy (CAP) and Internal Policies are 38\% and $11 \%$ of total commitments, respectively.

Table 1: Financial Package for Bulgaria, $€$ millions, 2004 prices

\begin{tabular}{|c|c|c|c|c|}
\hline Appropriations for Commitments & 2007 & 2008 & 2009 & 2007-2009 \\
\hline \multicolumn{5}{|l|}{ Common Agricultural Policy } \\
\hline Market measures & 132 & 129 & 127 & 388 \\
\hline Direct payments & 0 & 198 & 233 & 431 \\
\hline Rural development & 231 & 312 & 397 & 940 \\
\hline Total CAP & 363 & 639 & 757 & 1759 \\
\hline \multicolumn{5}{|l|}{ Structural Actions ${ }^{1)}$} \\
\hline Structural Funds & 311 & 438 & 577 & 1326 \\
\hline Cohesion Fund & 180 & 253 & 334 & 767 \\
\hline Total Structural Actions & 491 & 691 & 911 & 2093 \\
\hline \multicolumn{5}{|l|}{ Internal Policies } \\
\hline Existing policies & 88 & 89 & 91 & 268 \\
\hline Nuclear safety & 70 & 70 & 70 & 210 \\
\hline Institution building ${ }^{2)}$ & 10 & 7 & 3 & 20 \\
\hline Total Internal Policies & 168 & 166 & 164 & 498 \\
\hline \multicolumn{5}{|l|}{ Administration $^{3)}$} \\
\hline Compensation & 122 & 59 & 59 & 240 \\
\hline Total Commitment Appropriations & 1144 & 1555 & 1891 & 4590 \\
\hline
\end{tabular}

Source: Financial Package for Bulgaria and Romania, indicative allocations 2007-2009 based on Commission Communication of 10 February 2004 and EU Accession Treaty for Bulgaria and Romania of April 2005.

Notes: ${ }^{1)}$ The Accession Treaty was negotiated on the basis of the 2000-06 acquis, where rural development is financed under two funding sources: the EAGGF(European Agricultural Guidance and Guarantee Fund) Guarantee Section, and the EAGGF Guidance Section (as part of the Structural Funds). Future rural development allocations for the 2007-13 period will all be financed from a single fund, the new European Agricultural Fund for Rural Development (EAFRD), but they are derived from the two 2000-06 funding sources. Thus we have subtracted the funds available under the EAGGF Guidance from the Structural Funds and added them to the resources available for Rural development. ${ }^{2)}$ Institution building appropriations for commitments are calculated on the basis of a population key for Bulgaria and Romania. ${ }^{3)}$ No administrative costs are specifically allocated for Bulgaria. Therefore, no commitment and payment appropriations under this heading are included.

${ }^{2}$ Although the EU financial framework for 2007-2013 is yet to be determined, the European Council meeting in Thessaloniki has indicated that negotiations on the Financial Package for Bulgaria and Romania can be carried out. However, this package might be adapted to reflect policy reforms or overall changes to the financial perspectives for 2007-2013. For Bulgaria and Romania, the Financial Package is limited to a period of three years after their accession (2007-2009), following the same approach and phasing-in rules for structural actions and rural development as for the ten new EU members of 2004.

${ }^{3}$ Rural development allocations figures are based on the Accession Treaty for Bulgaria and Romania. 
Two instruments finance agricultural policy related actions. These are The European Agricultural Rural Development Fund (EARDF) and The European Agricultural Guidance and Guarantee Fund (EAGGF). Financing of structural action comes from The European Regional Development Fund (ERDP), the European Social Fund (ESF) and the Cohesion Fund. Annex I summarizes these financial instruments of the Union.

Despite the sizeable EU commitments to Bulgaria, actual disbursements (or payment appropriations) are expected to be significantly lower than the committed resources. The gap is estimated to be on average around $2.5 \%$ of output in the first three years (see Table 2). This variance between commitments and payments stems from important legal distinctions between the two types of appropriations. The EU commitment appropriations cover the total envelope for projects that are foreseen in documents for the programming period, as if they were to be carried out in their entirety during that period. Put differently, commitments cover legal obligations made during the fiscal year for actions which may occur over several years. Since some of the programs cannot be fully completed in the programming period, appropriations for payments are lower than the commitments for the planned projects every year. Appropriations for payments cover only costs actually incurred during the year (but that may be related to commitments for the current year as well as previous years). These estimates of appropriations therefore represent only a share of the committed resources.

Table 2: Payments and Commitments Appropriations’ Gap, 2007-2009, \% GDP ${ }^{4}$

\begin{tabular}{|c|c|c|c|}
\hline & Commitments & Payments & Gap between commitments and payments \\
\hline 2007 & $4.8 \%$ & $2.3 \%$ & $2.5 \%$ \\
\hline 2008 & $6.2 \%$ & $4.0 \%$ & $2.2 \%$ \\
\hline 2009 & $7.1 \%$ & $4.3 \%$ & $2.8 \%$ \\
\hline
\end{tabular}

Source: Own calculations based on Financial Package for Bulgaria and Romania from February 10, 2004 and EU Accession Treaty for Bulgaria and Romania

In addition, the size and the disbursement schedule of payment appropriations are often conditional. Payments from the Structural and Cohesion Funds as well as the remainder of preaccession aid are contingent on the implementation of specific projects. ${ }^{5}$ In addition, the utilization of available payments depends on the absorption capacity and may deviate from the $e x$ ante projected payments (as the ones presented in Table 4). Conversely, payment appropriations covering direct payments to farmers, market interventions in agriculture, budgetary compensations, and Schengen border-related expenditures are transfers that can be taken as actual future disbursements. Overall, in estimating the amount of payment appropriations for Bulgaria, full absorption of the payment appropriations (but not commitments) is assumed.

In sum, given the maze of rules governing EU resources to member states, determining the size of actual payment appropriations by type is key to correctly projecting the effects of Bulgaria's accession on both its balance of payments and national budget.

\footnotetext{
${ }^{4}$ For the calculations in percent of GDP and of GNI throughout the paper forecasts of the Agency for Economic Analysis and Forecasting have been used. GDP is projected at BGN 49021mn in 2007, BGN $53274 \mathrm{mn}$ in 2008 and BGN $57535 \mathrm{mn}$ in 2009. GNI projections for 2007, 2008 and 2009 stand at BGN 47965 mn, BGN 52003 mn and BGN 56144 mn, respectively.

${ }^{5}$ Structural Funds payments do not include payments from the EARDF.
} 


\section{DiRect Net BALANCE OF PAYMENTS IMPACt OF BUlgaria’s EU ACCESSION}

Upon accession Bulgaria and Romania will join a group of so called "cohesion countries" and will become net beneficiaries from the EU budget, i.e. the inflow of funds from the EU budget would be higher than the outflow of resources from Bulgaria to the EU. All flows of funds between the country and the EU are taken into account in order to estimate the net balance of payments effect for Bulgaria's EU accession. Payment appropriations are used in calculating the net effect of the country's EU accession, since it is only actual payments that have a macroeconomic impact on the recipient country. ${ }^{6}$

Based on the updated financial envelope presented above, net transfer of EU funds to Bulgaria is estimated to be on average $3.7 \%$ of the projected GDP in 2007-2009. The positive impact picks up significantly as a percentage of output in the first three years of accession. This is due to a gradual phasing-in of most of the EU funds and a higher rate than the expected real GDP growth (see Table 3). Net transfers to the country start at 2.6 percent of GDP in 2007 and build up to 4.2 percent of GDP in 2009. Each step in arriving at this result is outlined below.

Table 3: Net Balance of Payment Effect for Bulgaria (\% of GDP)

\begin{tabular}{|c|c|c|c|c|}
\hline \multicolumn{1}{|c|}{ Share in GDP } & $\mathbf{2 0 0 7}$ & $\mathbf{2 0 0 8}$ & $\mathbf{2 0 0 9}$ & $\mathbf{2 0 0 7 - 0 9}$ \\
\hline Inflow of funds & & & & \\
\hline Post-accession appropriations for payments & $2.3 \%$ & $4.0 \%$ & $4.3 \%$ & $3.6 \%$ \\
\hline Pre-accession appropriations for payments & $1.5 \%$ & $1.2 \%$ & $1.1 \%$ & $1.3 \%$ \\
\hline Total inflow of funds & $3.8 \%$ & $5.2 \%$ & $5.4 \%$ & $4.8 \%$ \\
\hline Outflow of funds & & & & \\
\hline Own Resources & $1.2 \%$ & $1.2 \%$ & $1.2 \%$ & $1.2 \%$ \\
\hline Contribution to the EIB & $0.007 \%$ & $0.007 \%$ & $0.013 \%$ & $0.009 \%$ \\
\hline Payment to the RFCS & $0.000 \%$ & $0.000 \%$ & $0.006 \%$ & $0.002 \%$ \\
\hline Total outflow of funds & $1.2 \%$ & $1.2 \%$ & $1.2 \%$ & $1.2 \%$ \\
\hline Net impact on Bulgaria & $2.6 \%$ & $4.0 \%$ & $4.2 \%$ & $3.7 \%$ \\
\hline
\end{tabular}

Source: Own calculations based on the Commission Communication of 10 February 2004, EU Accession Treaty for Bulgaria and Romania of April 2005 and Bulgarian Ministry of Finance estimations on the preaccession funds disbursements.

\section{Inflows of EU Funds to Bulgaria}

Total payments from the EU budget to Bulgaria comprise of total post-accession appropriations for payments and total appropriation of pre-accession aid.

\footnotetext{
${ }^{6}$ Hallet (2004) and Hallet and Keereman (2005) use the same approach in their work, too.
} 


\section{Post-Accession Payments}

Total amount of payment appropriations for the period 2007-2009 is projected at close to $€ 3$ bn in current prices, as shown in Table 4. EU transfers to Bulgaria's national budget in relation to CAP present nearly half of total payments appropriations. Structural Funds and the Cohesion Fund combined are around one third of the total payments. The remainder is shared between Internal Policies (12\%) and Budgetary compensations (9 \%).

Table 4: Payment Appropriations, $€$ mn, current prices ${ }^{\#}$

\begin{tabular}{|c|c|c|c|c|}
\hline & 2007 & 2008 & 2009 & 2007-2009 \\
\hline \multicolumn{5}{|c|}{ Common Agricultural Policy } \\
\hline Market measures & 140 & 140 & 140 & 420 \\
\hline Direct payments & 0 & 214 & 257 & 472 \\
\hline Rural development & 110 & 197 & 218 & 524 \\
\hline Total CAP & 250 & 551 & 615 & 1416 \\
\hline \multicolumn{5}{|l|}{ Structural Actions } \\
\hline Structural Funds & 155 & 277 & 307 & 740 \\
\hline Cohesion Fund & 6 & 49 & 113 & 168 \\
\hline Total Structural Actions & 161 & 327 & 421 & 908 \\
\hline \multicolumn{5}{|l|}{ Internal Policies } \\
\hline Existing policies & 34 & 58 & 80 & 172 \\
\hline Nuclear safety & 0 & 76 & 77 & 153 \\
\hline Institution building $^{1)}$ & 4 & 5 & 5 & 15 \\
\hline Total Internal Policies & 37 & 140 & 163 & 340 \\
\hline \multicolumn{5}{|l|}{ Administration $^{2)}$} \\
\hline Compensation & 129 & 64 & 65 & 258 \\
\hline Total Payments & 577 & 1081 & 1264 & 2922 \\
\hline
\end{tabular}

Source: Own calculations, based on theFinancial Package for Bulgaria and Romania, indicative allocations 2007-2009 based on Commission Communication of 10 February 2004 and EU Accession Treaty for Bulgaria and Romania of April 2005.

Notes: ${ }^{\#} 2$ percent per year deflator, routinely adopted by the EC for indexation of the EU funds, is used in these calculations. ${ }^{7}$ See Annex II for Payment Appropriations, € mn, in 2004 prices.

${ }^{1)}$ Institution building appropriations for commitments are calculated on the basis of a population key for Bulgaria and Romania. ${ }^{2)}$ No administrative costs are specifically allocated for Bulgaria. Therefore, no commitment and payment appropriations under this heading are included. ${ }^{3)}$ Payment appropriations in this table may differ from the calculated payments in the text below due to deflator-related base effects (see footnote 7 below).

\section{Common Agricultural Policy}

The first sub-heading under this chapter is Market Measures and includes export subsidies and expenditures to stabilize and regulate agricultural markets. Commitments covering market

${ }^{7}$ To arrive at estimates of the appropriations for commitments and payments in current prices, one can alternatively deflate them by projections of the national GDP deflator. We have opted for the 2 percent deflator routinely used by the EU, because the funds are allocated out of the EU budget, and not the national budget. 
measures are divided into roughly equal shares among the first three years of accession (see Table 1). Payments under these allocations are non-differentiated, i.e. payment is $100 \%$ made in the year of commitment. The amount for the period 2007-2009 is expected to be $€ 420 \mathrm{mn}$, at current prices.

Following the EC concerns that full integration of Bulgaria into the system of Direct Payments would not give the right incentives to farmers, a gradual build-up of the direct payment over a period of 10 years starting at 25\% of the level applicable to EU-15 has been adopted (as indicated in Table 1). For the period 2007-2009, the amount of payment appropriation is projected to be $€ 472 \mathrm{mn}$, in current prices.

Rural Development allocations for Bulgaria and Romania are calculated on the basis of the two countries' combined share in the total SAPARD funding up to 2003. Bulgaria alone will receive a part of it according to its relative share of utilized agricultural area and agricultural employment. In turn, payment appropriations for rural development are estimated at $€ 524 \mathrm{mn}$ in current prices for the period 2007-2009. As stipulated in the Financial Package from February 10, 2004 phasing-in of Bulgaria and Romania is based on the global rate of phasing-in foreseen for the introduction of structural funds to the ten new member states, calculations are made according to the schedule in Table $5 .^{8}$ The payments for 2007 are calculated by summing up $10 \%$ the total commitments for 2007-2009 for rural development (€1021 mn, current prices) and 3\% of the average annual commitments ( $€ 340 \mathrm{mn}$, current prices) for the same period. Similar computations are carried out for 2008 and 2009. The disbursement schedule has been agreed upon at the Copenhagen summit for the 2004 MNS and it is to be applied for Bulgaria and Romania as well. Thus, payment appropriations for rural development in Bulgaria are estimated at €112 mn, €197 $\mathrm{mn}$, and $€ 214 \mathrm{mn}$ in current prices for 2007, 2008, and 2009, respectively.

Table 5: Payments Schedule for Rural Development

\begin{tabular}{|l|c|c|c|c|}
\hline \multicolumn{2}{|c|}{ Type of Appropriations in € mn, current prices } & $\mathbf{2 0 0 7}$ & $\mathbf{2 0 0 8}$ & $\mathbf{2 0 0 9}$ \\
\hline \multirow{2}{*}{ Total Commitment Appropriations, 2007-09 } & & \multicolumn{2}{|c|}{ Advance (\% of total envelope) } \\
\cline { 3 - 5 } & & $10 \%$ & $6 \%$ & \\
\hline & & \multicolumn{2}{|c|}{ Reimbursements (\% of ann. avrg.) } \\
\cline { 3 - 5 } Annual Average Commitment Appropriations, 2007-09 & 340 & $3 \%$ & $40 \%$ & $63 \%$ \\
\hline \multicolumn{2}{|l}{ Total Calculated Payments Appropriations: } & $\mathbf{1 1 2}$ & $\mathbf{1 9 7}$ & $\mathbf{2 1 4}$ \\
\hline
\end{tabular}

Note: Disbursements are made over 7 years.

\section{Structural Actions}

According to the financial package for Bulgaria and Romania the Structural Actions' funds for Bulgaria amount to $€ 2.3$ bn in 2004 constant prices for the period 2007-2009. Table 1 indicates a somewhat smaller amount for Structural Actions because we have transferred the amounts available for EAGGF Guidance Section to the Rural Development heading. The indicative share of the Cohesion Fund in the total allocations is around one-third ( $€ 767 \mathrm{mn})$.

Structural Funds payments are calculated using the same schedule and deflators as rural development payments (see Table 6). To compute the payment appropriations for 2007, for example, we add $10 \%$ of the total 2007-2009 envelope of commitments appropriations of $€ 1441$ $\mathrm{mn}$ and $3 \%$ of the average annual commitment of $€ 480 \mathrm{mn}$ for the same period and arrive at the sum of €159 mn Structural Funds’ payment appropriations for 2007 in current prices. For the

\footnotetext{
${ }^{8}$ It is assumed that Bulgaria and Romania follow the disbursements schedule of commitments for NMS 10 agreed in Copenhagen. Also, allocations for rural development have increased according to the Accession Treaty as compared to the Financial Package from February 10, 2004.
} 
period 2007-2009, the amount of appropriations for payments in Structural Funds is $€ 740 \mathrm{mn}$, in current prices.

Table 6: Payments Schedule for Structural Funds

\begin{tabular}{|c|c|c|c|c|}
\hline \multicolumn{2}{|c|}{ Type of Appropriations in $€$ mn, current prices } & $\mathbf{2 0 0 7}$ & $\mathbf{2 0 0 8}$ & $\mathbf{2 0 0 9}$ \\
\hline \multirow{2}{*}{ Total Commitment Appropriations, 2007-09 } & 1441 & \multicolumn{2}{|c|}{ Advance (\% of total envelope) } \\
\cline { 3 - 5 } & & $10 \%$ & $6 \%$ & \\
\cline { 3 - 5 } & 480 & $3 \%$ & $40 \%$ & $63 \%$ \\
\hline \multirow{2}{*}{ Annual Average Commitment Appropriations, 2007-09 } & $\mathbf{1 5 9}$ & $\mathbf{2 7 9}$ & $\mathbf{3 0 3}$ \\
\hline
\end{tabular}

Note: Disbursements are made over 7 years.

Cohesion Fund allocations are disbursed differently than the Structural Funds and according to the scheme in Table 7. To calculate the amount of payments in each year, we sum up the allocated share of commitments for each of the three years multiplied by the actual size of commitment appropriations for the respective year. For example, only 3\% of the committed €191 $\mathrm{mn}$ will be appropriated as payments in 2007, while for 2008 payments will be $€ 48 \mathrm{mn}$ ( $21 \%$ of the 2007 commitments of $€ 191 \mathrm{mn}$ added to $3 \%$ of the 2008 commitments of $€ 274 \mathrm{mn}$ ). The size of payments appropriations for Cohesion Fund for the three year period after accession is $€ 165$ $\mathrm{mn}$ in current prices.

Table 7: Payments Schedule for the Cohesion Fund

\begin{tabular}{|l|c|c|c|c|}
\hline \multicolumn{2}{|c|}{ Type of Appropriations, in $€$ mn, current prices } & $\mathbf{2 0 0 7}$ & $\mathbf{2 0 0 8}$ & $\mathbf{2 0 0 9}$ \\
\hline Commitment Appropriations 2007 & 191 & $3 \%$ & $21 \%$ & $22 \%$ \\
\hline Commitment Appropriations 2008 & 274 & & $3 \%$ & $21 \%$ \\
\hline Commitment Appropriations 2009 & 369 & & & $3 \%$ \\
\hline \multicolumn{2}{|c|}{ Total Calculated Payment Appropriations: } & $\mathbf{6}$ & $\mathbf{4 8}$ & $\mathbf{1 1 1}$ \\
\hline
\end{tabular}

The size of the payments under Structural Actions from the EU to Bulgaria is $0.6 \%$ of GDP in 2007, and goes up to $1.4 \%$ in GDP in 2009, reflecting the assumed progressive increase of absorption capacity of the country. It should be taken into consideration that the size of the financial envelope which captures both Structural Funds and the Cohesion Fund, however, is capped at $4 \%$ of national GDP in any given year.

It should be noted that Structural Funds are intended to be used as incremental budget resources. They are subject to the principle of additionality and may not substitute national expenditures, but should rather lead to new projects (see Box 1). ${ }^{9}$ Although monitoring is rather soft and noncompliance does not invoke sanctions, additionality is a legal requirement and as such it affects our calculations. This principle implies that fiscal space needs to be made for the effective and efficient absorption of the inflow of money from the EU budget (not only Structural Funds) without unnecessary distortions. It is imperative to ensure that the underlying incentive structure does not encourage the mere generation of projects with no economic justification. In contrast, the principle of additionality does not apply to the Cohesion Fund, internal policies or transitional expenditures like budgetary compensations or nuclear safety payments.

\footnotetext{
${ }^{9}$ See Article 11(1) of Council Resolutions No. 1260/99, Official Journal L 161 of 26/06/1999.
} 


\section{Box 1: Principle of Additionality}

With the purpose of improving the effectiveness of the structural funds, the attribution of the latter is based on (i) programming, (ii) partnership, (iii) concentration and (iv) additionality principles. While (i)-(iii) contribute to the greater certainty and achievement of strategic objectives and more innovative and better targeted projects, additionality has proved somewhat controversial both in terms of effectiveness of implementation and of outcomes of its application.

The principle of additionality was adopted for the Community structural funds in 1989, and has been operative ever since. The main idea behind this prescript is that if EU structural funds are to make real impact on eligible regions, EU funding may not replace national structural spending of the Member States. Thus, the Member States are required to maintain at least the same level of national structural expenditure in real terms from one programming period to another.

Technically, the verification of the principle of additionality has been simplified in the 2000-2006 programming period and presently includes three stages - ex ante, midterm and ex post evaluations. Furthermore, the expenditure level to be maintained is determined taking into account the general macroeconomic conditions in which the financing is carried out, as well as certain specific situations such as privatizations and exceptional level of public spending during the reference period and any reductions in the structural funds assistance in the present programming period.

Additionality is perceived as an important requirement for the attribution of the EU structural funds. Article 11 of the Council Regulation laying down general provisions on the Structural Funds links this principle to the programming process at its various stages. If at the end of the programming period the EC concludes that the additionality has not been respected by a Member State, in theory it might consider reducing planned SF allocations in the following period. Still, verification of this rule has proved difficult and practically no sanctions are imposed in case of violation of the principle.

In addition to the practical implementation problems, there are also concerns on the most efficient application of the additionality principle. Additionality implies earmarking a certain amount of national funds for a specific type of projects. Hence its application might result in suboptimal public expenditures in terms of efficiency. In Bulgaria particularly, public finances are presently in a transition to programmatic budgeting. This means in its essence adopting an outcome-based funding scheme and moving away from the resource-based budgeting by focusing on a thorough analysis of the costs and benefits of all publicly financed activities. Earmarking a fixed amount of resources for a particular type of project would violate this principle and might lead to inefficiencies of public spending.

Taking into account the estimated increase in the overall public expenditure envelope (with its potential crowding-out of the private sector), and a significant deterioration of the national budget balance related to EU accession, the cost of inefficiencies related to additionality might be high. For Bulgaria, assuming full absorption, we estimate deterioration of the public finances from EU related expenditures at an average of 1.6 percent of GDP per annum in 2007-2009. After this initial three-year period, budget pressures could be even higher due to the gradual build-up of disbursements of structural actions funding as additional projects are phased in.

Meanwhile, low capital stock and high real income growth combined with bright prospects of EU accession respectively determine high investment and consumption growth in Bulgaria. With persisting private sector saving-investment imbalances, prudent fiscal policy is needed in order to contain current account deficits and avoid real exchange rate appreciation and loss of competitiveness. Thus in the context of limiting the expansionary effect of the public spending on the economy and reforming areas like health care and education, it is of high importance to make sure that the additionality requirement does not generate inefficiencies and achieve optimal allocation of budget resources.

Generally, the principle of additionality implies that EU funds should augment the available national resources in order to enhance the welfare of the Europeans. Thus, EU money might contribute to the implementation of certain large scale projects that would not have been possible to execute with national funds only. However, although there is already certain expertise in managing EU funds due to the experience of the pre-accession funds, achieving high effectiveness of the EU money spent remains a key challenge for the beneficiaries. As the third EC report on economic and social cohesion states, the focus on 
financial rather than strategic issues tends to lead to funds being spent where they are most easily absorbed instead of where they might be most effective.

Sources: Commission Communication February 2004, “Third Report on Economic and Social Cohesion”, COM (2004) 107(final). European Commission, “The Verification of Additionality for Objective 1,” The New Programming Period 2000-2006: methodological working paper 5, Directorate-General XVI: Regional Policy and Cohesion.

European Commission

\section{Internal Policies}

Internal policies heading comprises of three elements: existing policies, nuclear safety, and institution building. Mainly expenditures on education, culture, social affairs, energy, environment and research, related to the implementation of the acquis, are financed under this heading. Commitments under existing policies are additional resources to the $€ 200 \mathrm{mn}$ commitment under PHARE program for the 2000-2004.

Considering Existing Policies, payments are made according to the schedule in Table 8. In a similar way as for the Cohesion Fund payments, we sum up the commitments for 2007, 2008 and 2009 each multiplied by the respective share of payments in commitments. For the period 20072009, the total payment appropriations under this heading are estimated at $€ 171 \mathrm{mn}$ in current prices.

Table 8: Payments Schedule for Existing Policies

\begin{tabular}{|l|r|c|c|c|}
\hline \multicolumn{2}{|c|}{ Type of Appropriations, in $€$ mn, current prices } & $\mathbf{2 0 0 7}$ & $\mathbf{2 0 0 8}$ & $\mathbf{2 0 0 9}$ \\
\hline Commitment Appropriations 2007 & 93 & $36 \%$ & $25 \%$ & $20 \%$ \\
\hline Commitment Appropriations 2008 & 96 & & $36 \%$ & $25 \%$ \\
\hline Commitment Appropriations 2009 & 100 & & & $36 \%$ \\
\hline \multicolumn{2}{|c|}{ Total Calculated Payment Appropriations: } & $\mathbf{3 4}$ & $\mathbf{5 8}$ & $\mathbf{7 9}$ \\
\hline
\end{tabular}

Note: Disbursements are made over 5 years.

Bulgaria is also entitled to payments for Nuclear Safety, as the country has committed to decommissioning units 1 to 4 of the Kozloduy Nuclear Power Plant. In 2007-2009, the assistance stands at $€ 153 \mathrm{mn}$ in current prices. These payments aim to assist the country in the process and to address its consequences. They also cover measures for environmental upgrading, modernization of the conventional energy production, transmission and distribution sectors in Bulgaria and measures to improve energy efficiency, to enhance the use of renewable energy sources and to improve security of energy supply.

As per the Accession Treaty, in the first year of accession Bulgaria and Romania will receive a Transition Facility of $€ 82 \mathrm{mn}$ in 2004 prices for strengthening these countries' administrative and judicial capacity. This amount however has not been allocated between Bulgaria and Romania yet. Therefore, we have made two assumptions in order to incorporate these commitments into the 2007-2009 financial envelop for Bulgaria and Romania. The assumptions are:

(i) The total amount of $€ 82 \mathrm{mn}$ has been distributed between Bulgaria and Romania according to a key, which takes into account the population size of the two countries. Thus, Bulgaria is assumed to receive $24.7 \%$ of the committed $€ 82 \mathrm{mn}$ in 2004 prices, which amounts to $€ 20.3 \mathrm{mn}$ in 2004 prices for the three-year period of 2007-2009.

(ii) Payments under the heading Institution Building have been determined using the same schedule as for the existing policies, and as described in Table 9 below. The estimated amount of payments in current prices under this heading stands at $€ 14 \mathrm{mn}$ for 2007-2009. 
Table 9: Payments Schedule for Institution Building

\begin{tabular}{|c|c|c|c|c|}
\hline \multicolumn{2}{|c|}{ Type of Appropriations, in $€$ mn, current prices } & $\mathbf{2 0 0 7}$ & $\mathbf{2 0 0 8}$ & $\mathbf{2 0 0 9}$ \\
\hline Commitment Appropriations 2007 & 11 & $36 \%$ & $25 \%$ & $20 \%$ \\
\hline Commitment Appropriations 2008 & 8 & & $36 \%$ & $25 \%$ \\
\hline Commitment Appropriations 2009 & 4 & & & $36 \%$ \\
\hline \multicolumn{2}{|c|}{ Total Calculated Payment Appropriations: } & $\mathbf{4}$ & $\mathbf{5}$ & $\mathbf{5}$ \\
\hline
\end{tabular}

\section{Administration}

Commitments for Administration come to a total of $€ 346$ mn (in 2004 constant prices) for both Bulgaria and Romania, in the period 2007-2009. The administrative expenditures cover only accession-related expenditures such as increased interpretation and translation needs. As in the case of the ten NMS, payment appropriations for Administration are not incorporated in the total payments from the EU to Bulgaria as no administrative costs are specifically allocated to the country.

\section{Compensation}

According to the Accession Treaty some $€ 258 \mathrm{mn}$ in current prices will be allocated for Bulgaria in the form of temporary budgetary compensations. Budgetary compensations are earmarked to avoid worsening of Bulgaria's fiscal stance due to the application of the own resources rules in full from the first year of accession. Their aim is to support the implementation of the Schengen agreement and serve as a cash flow facility for the national budget. The exact amount for each of the years 2007-2009 has been determined at the negotiations and will be paid out totally in the year of commitment. For 2007, the appropriations for payments are $€ 129 \mathrm{mn}$ in current prices, which presents $0.5 \%$ of GDP in that year. The size of the temporary budgetary compensations decreases in the next two years to $0.2 \%$ of GDP in 2009.

\section{Pre-Accession Aid}

Pre-accession aid is the second pillar comprising the inflow of funds from the EU to Bulgaria. EU pre-accession aid consists of three main vehicles - ISPA, PHARE, and SAPARD - each described in Box 2. The three pre-accession funds aim to finance actions that would prepare future members (including Bulgaria) for catching up with EU standards and legislation. They also serve as learning instruments in preparation for the use of EU Structural and Cohesion Funds.

\section{Box 2: Pre-accession Financial Instruments}

Enormous investment is required if the candidate countries are to adapt their standards, especially their industrial and environmental norms, so as to comply with Community legislation when they join the Union. The pre-accession aid involves three main components:

(i) PHARE (originally called Poland and Hungary Assistance for the Reconstruction of the Economy) is a pre-accession fund. Its main aim is to finance institution building in all aspects of accession, including the management of the structural finds, telecommunications regulations, customs, health and safety, among others. Phare projects' goals are to adapt the candidate countries' administrative and legal systems and to develop their infrastructure. 
(ii) ISPA (Instrument for Structural Policies for Pre-accession) finances infrastructure development in the fields of the environment and transport It is the equivalent of the Cohesion Fund for the Member states.

(iii) SAPARD (Special Accession Program for Agriculture and Rural Development) aims at the modernization of agricultural and rural development.

Sources: For more on Pre-accession funds see Council Regulation (EC) No 1266/1999 of 21 June 1999 on coordinating aid to the applicant countries in the framework of the pre-accession strategy and amending Regulation (EEC) No 3906/89 at http://europa.eu.int/comm/employment_social/esf2000/regulations/pre-accession_aid/en.pdf

Disbursements of payments from the EU budget to Bulgaria are plotted on Figure 1, based on estimates done by experts from the Ministry of Finance. The size of pre-accession aid for the period 1999-2011 is estimated at $€ 2.56$ bn current prices, with over a half of these resources going through the Phare program. Pre-accession aid commitments will be terminated for Bulgaria after its suggested EU accession on January 2007, although disbursements under the preaccession instruments submitted before 2007 will continue even after accession. Thus, there are financial implications of these funds in the immediate period after accession which need to be accounted for when estimating the fiscal effect of accession. Based on the experts' estimates from the Bulgarian Ministry of Finance, pre-accession aid payments are $€ 1.04$ bn in the first three years of accession. Figure 1 below indicates that pre-accession disbursements will be actually made to a great extent after accession (although commitments are made only prior to accession). This is due to the gradual build-up of capacity to absorb EU funds and the longer duration of some of the infrastructure projects. ${ }^{10}$

Figure 1: Total Pre-Accession Aid, 1999-2011, $€$ mn

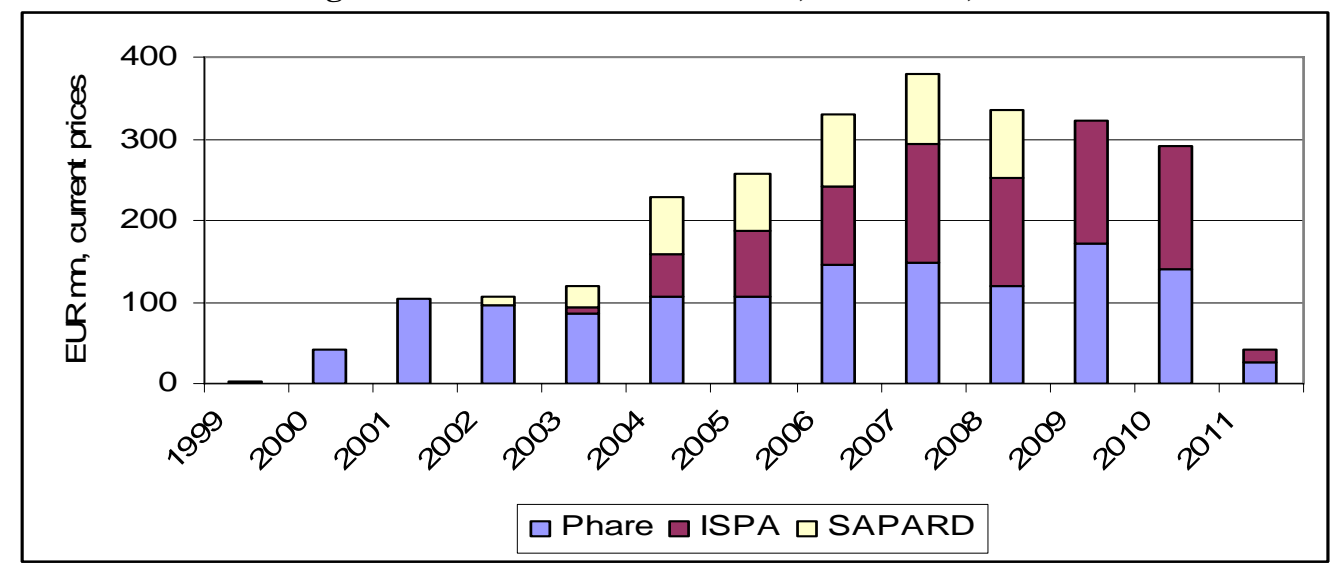

Source: MoF estimates.

\footnotetext{
${ }^{10}$ In the Middle-Term Fiscal Framework for 2006-2008 the Bulgarian Ministry of Finance estimates that the completion of the pre-accession projects would roughly coincide with the increase in EU payment appropriations, which would contribute for the smooth transition from financing under the pre-accession funds to the use of resources from the EU post-accession funds.
} 


\section{Outflow of National Funds to EU Budget}

\section{Own Resources}

The composition of member country's own resources in the EU budget consists of the following categories:

(i) Traditional own resources, comprised of:

a. Agricultural levies (duties charged on imports, sugar and isoglucose levies, applied under the common organization of the sugar market; there are no export duties in the EU, but if there were, those would be a part of the traditional own resources, too.)

b. Customs duties (common customs tariff on import from non-member states;)

(ii) VA resources represent revenue collected from VAT by the member states, which is derived from the application of a uniform rate to the VAT assessment base of each member state, harmonized in accordance with Community rules.

(iii) GNI-based additional resources represent a variable topping up resource to provide the revenue required to cover the total payment appropriations. It is calculated on the basis of budgeted appropriations for payments. ${ }^{11}$ This is the most sizeable total revenue source.

(iv) Reserves

(v) UK adjustment is a rebate on the UK payments to the EU budget. ${ }^{12}$

To arrive at the size of the estimated own resources payments for Bulgaria, we add (i) through (v), as presented in Table 10. Traditional own resources are transferred directly to the Commission, by-passing national budgetary procedures, while VAT and GNI resources as well as the UK rebate are paid through the national budget.

The Financial Perspective for 2007-2013 maintains the current level of ceilings for own resources amounting to $1.31 \%$ of EU GNI for appropriations for commitments and $1.24 \%$ of the total EU GNI for the payments. ${ }^{13}$ Lower ceilings were supported by the net contributors, as they would have paid less, while net beneficiaries like Bulgaria were in favor of higher ceilings, because the latter would result in a larger EU budget and, higher payments to the less developed countries of the Union.

Two assumptions are employed in calculating the size of own resources for 2009 in line with the Ministry of Finance expert estimates. These are: (i) own resources are around 1.2\% of GNI in the

\footnotetext{
${ }^{11}$ If the budgeted appropriations for payments are not fully disbursed, this may contribute to a surplus at the end of the year. This surplus will be taken into account in the budget of the following year and reduce the GNI own resources payments of that year accordingly.

Source: http://europa.eu.int/comm/budget/furtherinfo/index_en.htm

${ }^{12}$ The United Kingdom rebate was decided at the meeting of the European Council in Fontainebleau in 1984. The correction was only decided for the UK, which was then well below the EU average in terms of per capita prosperity. Nowadays the situation is very different (UK's GDP per capita in PPS is presently 9\% higher of the of the EU-15 average and 19\% higher than the EU-25 average), but it continues to receive a partial refund of its contributions, while other net contributors with similar or lower wealth per capita do not. The Commission has therefore proposed that the existing mechanism should be replaced by a generalized correction mechanism that applies to all main contributors, while ensuring that the financing cost for those that will not benefit from such a correction will not be excessive. This is done by limiting the total volume of the corrections to a maximum amount.

${ }^{13}$ See the Note from the Presidency of the Europan Council on the Financial Perspective 2007-2013 from

December 19, 2005 (http://ue.eu.int/ueDocs/cms_Data/docs/pressData/en/misc/87677.pdf).
} 
2007-2009 period; and (ii) their structure remains roughly the same in the first three years of accession. ${ }^{14}$ The estimated size of the own resources for the three-year period is $€ 954 \mathrm{mn}$.

Table 10: Contributions to the EU Budget, in current prices and share in GDP

\begin{tabular}{|l|c|c|c|c|}
\hline \multicolumn{1}{|c|}{$\begin{array}{c}\text { Own Resources Payments, } \\
\text { € mn, current prices }\end{array}$} & $\mathbf{2 0 0 7}$ & $\mathbf{2 0 0 8}$ & $\mathbf{2 0 0 9}$ & $\mathbf{2 0 0 7 - 0 9}$ \\
\hline Traditional own resources & 24.0 & 25.0 & 27.5 & 76.5 \\
\hline Resource based on VAT & 35.5 & 33.7 & 39.0 & 108.2 \\
\hline Resource based on GNI & 207.0 & 228.7 & 244.6 & 680.3 \\
\hline Reserve & 1.0 & 1.1 & 1.2 & 3.3 \\
\hline Great Britain Adjustment & 24.2 & 30.6 & 30.7 & 85.5 \\
\hline Total Own Resources & $\mathbf{2 9 1 . 7}$ & $\mathbf{3 1 9 . 1}$ & $\mathbf{3 4 3 . 0}$ & $\mathbf{9 5 3 . 8}$ \\
\hline
\end{tabular}

Source: Ministry of Finance, Agency for Economic Analysis and Forecasting and own calculations

\section{Payments for the subscribed capital share in the EIB}

As per the Treaty of Accession of Bulgaria and Romania to the European Union, upon accession Bulgaria should pay EUR $14.8 \mathrm{mn}$ corresponding to the share of the country of the capital paid in the subscribed capital of the European Investment Bank. New members subscribe only 5\% of their share in eight equal shares till end-2011. These amounts are based on GDP and population keys for each of the countries. In 2007 and 2008 only one payment per year is envisaged, while in 2009-2011 two disbursements annually should be made.

Bulgaria will also have to make payments to the EIB, based on its obligation to cover EIB reserves. However this amount has not been fixed yet and should not be of important size. It is therefore not included in our calculations.

It should be mentioned that upon entry to the European Monetary Union (EMU), Bulgaria will also have to pay for membership to the European Central Bank (ECB), equal to only 5\% of its capital share. The payments will be one-off and will be borne by the Bulgaria National Bank (i.e. it will have no immediate effect on the budget).

\section{Payments to the Research Fund for Coal and Steel}

The Accession Treaty for Bulgaria and Romania also envisages a payment of certain amounts to the Research Fund for Coal and Steel. Bulgaria's contribution to this fund in particular amounts to EUR $11.95 \mathrm{mn}$ in current prices. It should be made in four installments starting in 2009 and paid as follows, in each case on the first working day of the first month of each year: 2009: 15\%, 2010: 20\%, 2011: 30\%, 2012: 35\%.

\section{DiRECt Net EFFECT OF EU ACCESSION ON THE NATIONAL BUDGET}

Whereas the calculation of the EU funds' impact on the Bulgarian balance of payment is straightforward, the estimation of the purely budgetary effect reflects the rules under which different EU funds are allocated.In addition, EU accession has additional direct and indirect effects on the revenue side of the budget due to the alignment of the national legislation with the acquis communautaire and second-round positive impacts of EU accession on trade integration,

\footnotetext{
${ }^{14}$ See Footnote 4 for the Agency for Economic Analysis and Forecasting estimations of GNI for 20072009.
} 
investment and growth, which are not taken into account in this paper.We estimate only the direct effects on the budget balance on a cash basis, assuming that all EU related public expenditures would be recorded in the consolidated fiscal program.

In sharp contrast to the overall effect presented in section C, the EU transfers are estimated to deteriorate the country's fiscal position by about 1.6 percent of GDP on average during 2007-09, if all available funds are absorbed and the expected EU accession is not accompanied by a restructuring of the fiscal framework (see Table 11). The impact on the budget on a cash basis is front-loaded, with the budget balance projected to deteriorate by 2.0 percent of GDP in 2007 and budget strains diminishing to 1.3 percent of GDP by 2009, despite an increase in the overall flows over time. ${ }^{15}$ Our results are consistent with previously carried out research in this area as the majority of studies of the fiscal impact of EU accession arrive at positive long-term effect and negative short-term effects. ${ }^{16}$

Table 11: Summary of the Net Fiscal Effect Calculation (as \% of GDP)

\begin{tabular}{|c|c|c|c|c|}
\hline \multicolumn{1}{|c|}{ Share in GDP } & $\mathbf{2 0 0 7}$ & $\mathbf{2 0 0 8}$ & $\mathbf{2 0 0 9}$ & $\mathbf{2 0 0 7 - 0 9}$ \\
\hline Effect on the budget revenues & & & & \\
\hline Own Resources related decrease in revenues & $-0.2 \%$ & $-0.2 \%$ & $-0.2 \%$ & $-0.2 \%$ \\
\hline Net effect on revenues & $-0.2 \%$ & $-0.2 \%$ & $-0.2 \%$ & $-0.2 \%$ \\
\hline Effect on the budget expenditures & & & & \\
\hline Own Resources related increase in expenditures & $0.9 \%$ & $1.0 \%$ & $0.9 \%$ & $0.9 \%$ \\
\hline Contribution to the EIB & $0.007 \%$ & $0.007 \%$ & $0.013 \%$ & $0.009 \%$ \\
\hline Payment to the RFCS & $0.000 \%$ & $0.000 \%$ & $0.006 \%$ & $0.002 \%$ \\
\hline Co-financing of EU programs & $0.7 \%$ & $0.8 \%$ & $0.8 \%$ & $0.8 \%$ \\
\hline $\begin{array}{c}\text { Substitution of expenditures due to non-additionality } \\
\text { of the Cohesion Fund }\end{array}$ & $0.0 \%$ & $-0.2 \%$ & $-0.4 \%$ & $-0.2 \%$ \\
\hline $\begin{array}{c}\text { Possible budget savings from agricultural subsidies if } \\
\text { there are no top-ups }\end{array}$ & $-0.2 \%$ & $-0.2 \%$ & $-0.2 \%$ & $-0.2 \%$ \\
\hline$\quad$ Pre-financing of direct payments under the CAP & $0.9 \%$ & $0.2 \%$ & $0.1 \%$ & $0.4 \%$ \\
\hline Net effect on expenditures & $2.3 \%$ & $1.6 \%$ & $1.3 \%$ & $1.7 \%$ \\
\hline Budgetary compensation & $0.5 \%$ & $0.2 \%$ & $0.2 \%$ & $0.3 \%$ \\
\hline Net fiscal effect & $-2.1 \%$ & $-1.6 \%$ & $-1.3 \%$ & $-1.6 \%$ \\
\hline
\end{tabular}

\section{Direct Effects on National Budget Revenues}

The main channels through which national budget revenues are to be affected are (i) the expected decline in receipts from VAT and customs due to their inclusion in the Bulgarian contribution to the EU budget and (ii) the increase in excises to achieve harmonization with the EU. Concerning VAT, EU value added tax collection does not rely on border control, so lower VAT revenues are expected in the post-accession period in countries where VAT collection was efficient before. Meanwhile, some $75 \%$ of the customs revenues are intended to go directly to the EU budget

\footnotetext{
${ }^{15}$ More thorough schematic representation of the calculation of the net budgetary effect of EU accession is given in Table 15 in Annex III.

${ }^{16}$ See for instance, Kopits and Szekely (2002) calculate negative impacts for the national budgets of Czech Republic, Estonia, Hungary, Poland and Slovakia, which vary between 3 and 5\% of GDP. Backe (2002) and Antczak (2002) also obtain negative immediate effects of EU accession on the budgets of the acceding countries.
} 
(under the traditional own resources heading), while the remainder is kept by the respective member state to cover collection costs. Additionally, there would be downward pressure on custom duties revenue different form traditional own resources. It would come from the fact that trade relations between Bulgarian and the rest of the EU states would be fully liberalized. Still, taking into account the already low tariffs on the industrial goods even before accession, no significant losses of revenues are expected from the application of the Common External Tariff of the EU.

Second, excise taxes are lower in Bulgaria than required in the acquis. Theoretically, their gradual alignment with the EU legislation should expand revenue receipts for this item, as consumption of goods on which excises are levied is assumed to be less sensitive to price changes and no significant substitution effects are expected. Overall the above-discussed revenue effects are expected to cancel out more or less each other and have a less significant impact on the total budget revenues.

\section{Direct Effects on National Budget Expenditures}

We consider four groups of effects of EU accession on the expenditure side of the national budget, namely: expenditures on own resources, co-financing, substitution of expenditures, and pre-financing of direct payments under CAP.

\section{Expenditures on own resources}

While own resources would be financed though the allocation of a part of the tax revenues directly to the EU budget, GNI-based resources, reserves and the UK rebate would boost expenditures. In the case of Bulgaria, out of the total own resources of $€ 954 \mathrm{mn}$ in current prices in 2007-2009, some $€ 185 \mathrm{mn}$ would diminish the national budget revenues and the remaining sum should enter the expenditure side of the budget. As the Bulgarian government is committed to keeping the budget expenditures under $40 \%$ of GDP, there should be significant restructuring of the budget expenditures in order to accommodate these payments to the EU budget.

\section{Co-financing}

Table 12 presents our estimates of co-financing requirements in current prices implicitly supposing that the funds will be fully absorbed. In case this assumption does not hold, EU payments under the structural actions will be smaller and most probably would require smaller co-financing. However, the net effect for the country would be smaller as well. Total co-financing is calculated as a sum of co-financing of Structural Funds and the Cohesion Fund, pre-accession programs and rural development, as calculated above. We have also taken into account the fact that the new EU financial perspective for 2007-2013 allows for higher EU participation in the various projects (up to $85 \%$ of the total funding of projects under the Structural Funds and the Cohesion Fund). ${ }^{17}$

\footnotetext{
${ }^{17}$ See footnote 13 giving a reference for more detailed information on this issue as well as Article 51 and 52 from the European Commission Proposal for a Council Regulation laying down general provisions on the European Regional Development Fund, the European Social Fund and the Cohesion Fund of July 14, 2004.
} 
Table 12: Co-financing

\begin{tabular}{|l|c|c|c|c|}
\hline Co-financing, in mn current $€$ & $\mathbf{2 0 0 7}$ & $\mathbf{2 0 0 8}$ & $\mathbf{2 0 0 9}$ & $\mathbf{2 0 0 7 - 0 9}$ \\
\hline Rural development & 27 & 49 & 54 & 131 \\
\hline Structural funds & 27 & 49 & 54 & 131 \\
\hline Cohesion fund & 1 & 9 & 20 & 30 \\
\hline Pre-accession aid & 126 & 112 & 107 & 345 \\
\hline Total & 182 & 219 & 236 & 637 \\
\hline
\end{tabular}

Source: Pre-accession aid data from the Ministry of Finance.

Co-financing needs and Structural Funds additionality requirements are both taken into account in calculating the net budgetary effect of the accession. We assume that two offsetting effects take place. On the one hand, the maximum contribution of EU funds will not be allocated for all measures as there is interest to increase the number of the EU-financed projects (i.e. allocate a smaller amount for each project). ${ }^{18}$ Therefore, national co-financing might be higher than $15 \%$ for the Structural Funds and, the Cohesion Fund and 20\% for Rural Development. On the other hand, a part of this co-financing will come from private sources and bear no effect on the state budget. Taking into account these two considerations, it is assumed that they would mostly cancel out each other. ${ }^{19}$ This reasoning is generally in line with the Bulgarian Ministry of Finance expectations too. Therefore, our calculations are based on the assumption that the national cofinancing will amount to $15 \%$ of total funding (or $18 \%$ of the allocated EU funds) for Structural Funds and the Cohesion Fund; and 20\% of total funding (or 25\% of the allocated EU funds) for Rural Development.

As per pre-accession aid, the co-financing requirement is one third of pre-accession payments appropriations. Due to the gradual phasing-in for all structural actions of the EU, co-financing requirements for Structural Funds, the Cohesion Fund and Rural Development increase as well during the period under consideration. Following the opposite tendency, co-financing of the preaccession aid subsides in 2007-2009.

\section{Substitution of expenditures}

As the Cohesion Fund alone is not subject to the principle of additionality, expenditures made under this fund might substitute other budget expenditures. With respect to the Structural Funds, full compliance with the principle of additionality is required (see Box 1). This implies that Structural Funds may not substitute existing budget expenditures and therefore may not improve the budget balance of a member state.

Budget savings may be realized also in the substitution of national agricultural subsidies with the direct payments under the Common Agricultural Policy, assuming that there will be no top-ups out of national resources. The latter is achievable since in the case of Bulgaria the income effect for the agricultural producers from the EU direct payments is expected to be significant and further national subsidies might distort considerably the decisions of the Bulgarian farmers.

\section{Pre-Financing of Direct Payments under CAP}

Direct payments to the farmers might or might not add to the fiscal balance deterioration depending on whether they are paid out in December 2007 or in early 2008. The payment scheme for these subsidies is as follows:

\footnotetext{
${ }^{18}$ National authorities usually prefer having a higher number of projects so that if certain projects fail they would have headroom and would still be able to absorb the allocated EU funds.

${ }^{19}$ Hallet (2004).
} 
- Agricultural producers apply for such assistance till end-April.

- The applications are processed and controlled until October.

- The national paying agency can only make the payments to the farmers in the period between December 1, 2007 and June 30, 2008.

- The national funds used for direct income support for the farmers are reimbursed within 2.5 months of their expenditures by EU. Moreover the EU allocations for direct payments charged to the EU budget year $\mathrm{N}$ cover expenditures of the paying agencies between October 16 of the year N-1 and October 15 of the year N.

This procedure implies two alternatives for the Bulgarian government with a significant impact on the national budget on a cash basis: (i) the payments to the farmers out of national resources can be made in the period between January and June of the following year. Thus, both national and EU expenditures will be made in the same fiscal year; (ii) if the direct payment system runs smoothly - there are no problems with the eligibility criteria and the applications are good payments might be made in December. In this case, payments will be reimbursed only in early 2008 and will put pressure on the national budget on a cash basis. However, when determining the formal compliance with the Maastricht budget criteria, pre-financing of CAP direct payments will not be taken into account in the budget deficit compilation, as the ESA-95 accounting standards are accrual-based.

In this work the second, the more conservative scenario has been assumed, implying national payments and EU reimbursements being made in different fiscal years. The last row of Table 15 indicates that in case the direct payments to the Bulgarian farmers for 2007 are delayed beyond December 2007, the overall negative effect for the Bulgarian budget would amount to $1.2 \%$ of GDP in 2007 (as compared to 2.1\% of GDP). In terms of averages for the whole 2007-2009 period this is equivalent to $1.3 \%$ of GDP as compared to $1.6 \%$ of GDP.

\section{E. FisCAL, INSTITUTIONAL AND MACROECONOMIC CHALLENGES}

\section{Fiscal challenges}

Bulgaria faces important fiscal challenges related to effective utilization of the EU funds. These are related to the improvement of the budget procedures, restructuring of the public spending to accommodate EU-related expenditures and enhancing the institutional capacity of absorbing the funds. Bulgaria and Romania have a fixed financial package for only the first three years of accession. During this period the countries would learn to absorb efficiently funds, with the challenge being not so much in the process of getting the projects ready and running, but more in ensuring the proper management and evaluation of the projects, so that once a project is completed the transfer of EU funds would be effectuated smoothly. Lessons from other new member states may well bear a great relevance to Bulgaria (see Box 2).

\section{Box 2: Effective Use of EU Funds: Lessons}

Observers have emphasized four important and transferable to the new member states lessons on how to effectively use the EU funds:

a) Develop a clear strategic vision at all levels. In this respect the development of the National Development Plan aims at the alignment of strategies at national, regional and local levels to ensure that funds have cumulative and long-term impact on growth rather that being allocated on one-off projects. 
b) Encourage public-private partnerships to ensure high-quality and commercially viable projects that at the same time promote public sector goals. Cooperation between the private sector and the public bodies permits to the public sector to overcome its budget constraints and focus more on the profitability and viability of the projects. Private companies, on the other hand, gain possibilities to share risk and take on more businesses.

c) Obtain involvement in the projects at the municipality level. The EU will insist on a simpler, more transparent and decentralized system from 2007 on. Higher participation of the local governments is crucial for better management of the projects. Additionally municipalities can be actively involved in the attraction of private funds for co-financing of EU funds.

d) Take into account the EU funds inherent inflexibility. EU regulations and national authorities impose tight restrictions on the use of funds under the structural actions. With the exception of the grants available for small and medium-size enterprises, private companies generally benefit from EU funds indirectly, though tenders and public-private partnerships.

Source: Meth-Cohn and Shields (2005)

At the national level, there is an acute need for restructuring of the budget procedures to maximize the absorption capacity for the EU funds. Bulgarian government is in the process of a gradual introduction of two important fiscal management practices, which should facilitate fiscal adjustments. These are: (i) adoption of a middle-term fiscal framework, which should reinforce the government commitment to the targeted path of fiscal reforms, and (ii) introduction of a performance-based budgeting, which should make public expenditures more efficient.

The argument that public expenditures need to be made more efficient is further reinforced in Table 11, which indicates that the deterioration of the national budget balance after accession would stem more from increased expenditures, rather than from lower revenues. Taking into account the already high share of the government in the economy (government expenditures-toGDP ratio amounted to $40 \%$ in 2004), it is essential to improve the ability of the government to substitute existing expenditures with EU funds, i.e. to reorganize the structure of the budget in a most efficient way. Fiscal space needs to be made for expanding EU-related capital expenditures, for liquidity reasons and for the national contribution to the EU budget. The need for restructuring stands even more acutely in the light of the expanding social spending, related to the rapidly aging population and high unemployment.

The experience of the NMS-8 points to significant potential for fiscal consolidations, the sources of which stem from: (i) reduced public expenditure achieved via reducing spending on direct or indirect subsidies, rationalizing social transfer programs, enhancing the efficiency of health care and education systems, and streamlining public administration; (ii) strengthened tax administration, broadened tax bases, and reduced tax expenditures; (iii) advanced privatization agenda; (iv) strengthened public finance management. ${ }^{20}$

Data published in European Commission (2005b) indicates that successful fiscal consolidations in the NMS-8 prior to accession have been inevitably accompanied by cuts in public spending, going as high as 18.7 percentage points of GDP in Slovakia between 2000 and 2003. Furthermore, while capital expenditures have generally grown, current spending has been significantly reduced in the group of successful reformers. Largest cuts were made in social transfers and in the compensation of employees. Interest expenditures have decreased as a result of the favorable international conditions and debt restructuring in some of the NMS-8 countries.

\footnotetext{
${ }^{20}$ See World Bank 2005.
} 


\section{Institutional challenges}

Both the improvement of the budgeting process and the optimization of public expenditures are closely related to the absorption capacity of the recipient country, i.e. on the extent to which a member-state is capable of spending the structural fund resources allocated to it in an efficient and effective way. Preliminary discussions seem to reveal an institutional capacity that varies tremendously among the Bulgarian line ministries. If these structures do not invest in upgrading the skills of their personnel, the absorption of funds might suffer.

Administrative problems such as lack of monitoring and management skills, which do not allow the region to direct all incoming funds to productive investment is another institutional constraint which might affect the utilization of structural resources from the EU. Kalman (2002) adds that these problems can never disappear completely, but can be reduced if administrative capacity is improved and if the flow of funds is predictable. Indeed, recent UNDP Assessment of the Municipal and District Capacities for Absorption of the EU Structural and Cohesion Funds (2004) specifies four problematic aspects of the EU funds absorption at the municipal level in Bulgaria. These are namely weaknesses in:

(i) Organizational Capacity: while administrative structures for the formulation and implementation of projects at the municipal level have been established, there is need of an establishment of problem-oriented interactive mechanisms of communication and transparency, particularly on sensitive issues such as project selection.

(ii) Project Capacity: there is a risk that the EU funds rather than contributing to the alleviation of regional disparities may actually contribute to exactly the opposite: large and wealthier municipalities with experience in projects and capacities continue to be more successful in accessing EU funds at the expense of small and poorer municipalities with less project experience and capacities.

(iii) Planning Capacity: municipal plans prove to be more presentational documents rather than operational. The municipal planning is still perceived as a closed process, without vision for vertical and horizontal links within the overall national planning process. Therefore, further clarification of processes, meaning and function of the planning documents and procedures are needed.

(iv) Training Needs: Capacity varies considerably across municipalities and regions. Although a large number of training programs have been implemented, a relatively small number of municipal representatives have been trained.

\section{Macroeconomic challenges}

The net balance of payments effect for the country presented in Table 3 suggests sizable inflows of funds to the country. If there is no fiscal adjustment, the budget position would be expansionary. Higher capital inflows and fiscal expenditures would in turn put inflationary pressure on domestic prices. A real appreciation of the local currency would largely lower the competitiveness of Bulgarian exports. ${ }^{21}$ Another way to deal with high inflows of funds from abroad is to sterilize them by selling government bonds at the local security market. This would also have negative consequences as it would increase domestic interest rates and discourage foreign investors.

The Bulgarian Balance of payments' positions might be additionally aggravated by two other macroeconomic implications of the EU accession. First, the capital base in Bulgaria is low, so the

\footnotetext{
${ }^{21}$ The Bulgarian economy is functioning under a Currency Board Arrangement and the Bulgarian lev is pegged to the euro. Hence domestic inflation translates directly into a real exchange rate appreciation.
} 
marginal product of capital is high and thus profitability is higher in Bulgaria as compared to the EU-15. Therefore, large capital inflows might be expected. Second, after the accession to the European Union, Bulgarian consumers would expect their income to increase steadily and converge slowly to the average EU level. As EU funds present a positive income shock for the recipient country, permanent income hypothesis implies present consumption would increase at the expense of future consumption (i.e. savings), which would additionally widen the current account deficit. Put differently, the EU financial resources might be used to achieve higher current consumption instead of the future one (reachable through higher investment).

\section{F. CONCLUDING REMARKS}

The main goal of the EU funds transferred to the member states is to foster economic development and external and internal convergence. The experience in the EU-15 shows that the EU structural and cohesion funds can play an important role in accelerating the catch-up process and growth in the new member states. ${ }^{22}$ The EU accession is an opportunity for Bulgaria should it successfully utilize these resources and ultimately converge with the rest of the EU.

The projections presented in this paper suggest that while the overall effect for Bulgaria of EU accession is expected to be highly positive, the purely fiscal effect would be negative (see Table 13). These results are consistent with economic theory and previously research in this area also arrives at negative budgetary effects of EU accession. ${ }^{23}$

Table 13: Comparison between the Balance of Payments and Budget Direct Effects of Bulgaria's EU accession, EUR mn, current prices, 2007-09 ${ }^{24}$

\begin{tabular}{|l|c|c|}
\hline & Bulgaria & $\begin{array}{c}\text { National } \\
\text { Budget }\end{array}$ \\
\hline Post-accession appropriations for payments & $3.6 \%$ & \\
\hline o/w Budgetary compensation & & $0.3 \%$ \\
\hline Pre-accession appropriations for payments & $1.3 \%$ & \\
\hline Total inflow of funds & $4.8 \%$ & $0.3 \%$ \\
\hline Own Resources & $1.2 \%$ & $1.2 \%$ \\
\hline Contribution to the EIB & $0.009 \%$ & $0.009 \%$ \\
\hline Payment to the RFCS & $0.002 \%$ & $0.002 \%$ \\
\hline Co-financing & & $0.8 \%$ \\
\hline Pre-financing of direct payments & & $0.4 \%$ \\
\hline Possible substitution of expenditures under the Cohesion fund & $-0.2 \%$ \\
\hline Possible budget savings from agricultural subsidies if there are no top-ups & & $-0.2 \%$ \\
\hline Total outflow of funds & $1.2 \%$ & $1.9 \%$ \\
\hline Net Effect & $3.7 \%$ & $-1.6 \%$ \\
\hline
\end{tabular}

The budgetary effects considered here touch upon only the fiscal aspect of the expected overall impact of the EU funds on the economy. If effectively used these funds should contribute to economic growth both in the short and long terms. In the short term, they would create higher

${ }^{22}$ See Meth-Cohn and Shields (2005)

${ }^{23}$ See e.g. Kopits and Szekely (2002), Backe (2002), and Antczak (2002)

${ }^{24}$ For more details see Table 15. 
domestic demand. In the long term if invested in the improvement of the physical and human capital in the country, they should have contribution to economic growth from the supply side.

Experience in the EU-15 indicates that if misused, these resources can have only short-term demand-driven positive effect on the economy and add up to the poor governance problem and aid-dependency of the country. Funds are most effective if they are realized under broader, welldefined strategic programs. Although weighting varies among countries, main priorities for each of the new member states as well as Bulgaria are infrastructure and rural development. Other important areas where EU funds are directed are education, environment and development of the small and medium size businesses. It is mostly investments in physical and human capital that can generate increased spill-over benefits to the rest of the economy, and thus, raise productivity and output. 


\section{REFERENCES}

Accession Treaty for Bulgaria and Romania

Antczak, M. 2003, “Do Acceding Countries Need Higher Fiscal Deficits?” Warsaw.

Backé, P. 2002, "Fiscal Effects of EU Membership for Central European and Baltic EU Accession Countries”, Oesterreichische Nationalbank (ed.): Focus on Transition 2/2002, Vienna.

Council Resolutions No. 1260/99, Official Journal L 161 of 26/06/1999. Brussels.

Council Regulation (EC) No 1164/94 of 16 May 1994 establishing a Cohesion Fund [Official Journal L 130 of 25.05.1994].

Council Regulation (EC) No 1258/1999 of 17 May 1999 on the financing of the common agricultural policy Official Journal L 160 , 26/06/1999 P. 0103 - 0112

Council Regulation (EC) No 1264/1999 of 21 June 1999 amending Regulation (EC) No 1164/94 [Official Journal L 161 of 26.06.1999];

Council Regulation (EC) No 1265/1999 of 21 June 1999 amending Annex II to Regulation (EC) No 1164/94 [Official Journal L 161 of 26.06.1999].

Council Regulation (EC) No 1783/1999 of the European Parliament and of the Council of 12 June 1999 on the European Regional Development Fund [Official Journal L 213 of 13.08.1999]

Council Regulation (EC) No 1784/1999of the European Parliament and of the Council of 12 July 1999 on the European Social Fund [Official Journal L 213 of 13.08.1999];

Council Regulation laying down general provisions on the European Regional Development Fund, the European Social Fund and the Cohesion Fund (COM(2004) 492 final of 14 July 2004), at http://europa.eu.int/eurlex/lex/LexUriServ/site/en/com/2004/com2004_0492en01.pdf.

Council's Agreement on a Proposal for a Council Decision on Community strategic guidelines for Rural Development (Programming period 2007-2013) 2005/0129 (CNS)

European Commission, 2004a, Communication from the Commission, SEC(2004) 160 final and the Association Treaty between Bulgaria and Romania and the EU, at http://europa.eu.int/comm/enlargement/negotiations/treaty_of_accession_2005/index.htm Brussels.

European Commission, 2005b, “General Government Data, Part II: Data By Series”

Meth-Cohn D. and K. Shields, 2005, "Accessing EU Funds in the new member states: Best Practice from Around Europe”, Economist Corporate Network briefing paper.

Eurostat News Release STAT/05/22 of 15 February 2005. "The treatment of transfers from the EU budget to the Member States.” Brussels.

Financial Package for Bulgaria and Romania, published in a European Commission Communication from February 10, 2004

Hallet, M. 2004. "Fiscal Effects of Accession in the New Member States,” European Commission DG EcoFin working paper No. 203. Brussels. 
Hallet, M. and F. Keereman. 2005. "Budgetary Transfers between the EU and the new Member States: manna from Brussels or a fiscal drag?” ECFIN Country Focus, Vol 2 (2). European Commission. Brussels.

Kalman, J., 2002, "Possible Structural Funds Absorption Problems, The Political Economy View with Application to the Hungarian Regional Development Institutions and Financial System”, in Marcou G. eds. Regionalization for Development and Accession to the European Union: A Comparative Perspective, Local Government and Public Service Reform Initiative, Open Society Institute, Budapest.

Kopits, G. and I. Székely 2002, "Fiscal Policy Challenges of EU Accession for the Baltics and Central Europe", presented at a conference organized by the Oesterreichische Nationalbank in Vienna, November 3-5, 2002.

Ministry of Finance of Republic of Bulgaria. 2005. "Middle-Term Fiscal Framework 2006-08.” Sofia.

The Presidency Conclusions of the Copenhagen Summit of December 2002, at http://ue.eu.int/ueDocs/cms Data/docs/pressData/en/ec/73842.pdf

World Bank, 2005, "Selected Issues in Fiscal Reform in Central Europe and the Baltic Countries 2005” 
Annex I

\section{EU Financial Instruments}

\section{Financing of the European Regional Development Policy}

The European Regional Development Fund (ERDF) was set up in 1975 to stimulate economic development in less prosperous regions of the European Union. With the expansion of the EU, the ERDF has developed into a major instrument for helping to redress regional imbalances. The aim of the Fund is to promote economic and social cohesion by correcting the main regional imbalances and participating in the development and convergence of regions, while ensuring synergy with assistance from the other Structural Funds. In order to reduce the gap between the levels of development of the various regions and the extent to which the least-favored regions are lagging behind, the ERDF contributes to the harmonious, balanced and sustainable development of economic activity, to a high degree of competitiveness, to high levels of employment and protection of the environment, and to equality between women and men. The ERDF contributes through productive investment towards financing measures in the areas of infrastructure, creation and maintenance of sustainable jobs, local development and employment initiatives and the activities of small and medium-sized enterprises, innovation, education, culture and health, among others. Thus, as a financial instrument the ERDF would serve all three regional development policy objectives proposed by the Commission and presented in the Table below.

The European Social Fund (ESF) supports projects with the aim to prevent and combat unemployment, develop human resources and foster social integration in the labor market, so as to promote a high level of employment, equal opportunities for men and women, sustainable development and economic and social cohesion. In particular, it assists the measures taken in line with the European strategy and guidelines on employment. The ESF-funded projects aim to guarantee consistency and complementarity in the measures taken to improve the workings of the labor market, develop human resources, increase the adaptability of workers and enterprise, enhance access to employment and increase participation in labor markets, reinforce social inclusion, among others. As a financial instrument, the ESF serves the Convergence and Regional Competitiveness and Employment objectives (see Table below).

The Cohesion Fund aims to strengthen the economic and social cohesion at the level of the Community by financing groups of projects forming a coherent whole, in the fields of the environment infrastructures and trans-European transport networks. In order to respond to the particular needs of the NMS, the Cohesion Fund supports projects such as rail, maritime, inland waterways, multinational transport programs, urban transport and environmentally important investments in the areas of energy efficiency and renewable energies. It will apply to Member States with GNP lying below $90 \%$ of the Community average. The assistance which the Fund provides is conditional to the fulfillment of the conditions of economic convergence and the necessity to avoid public deficits. As a financial instrument is serves solely the Convergence objective (see Table below).

At the operational level, the new Council Regulation on the EU Funds, envisions that the number of funds will be limited to the above-described three funds (ERDF, ESF and Cohesion Fund). As opposed to current multi-Fund programs, future ERDF and ESF interventions would aim at operating with only one fund per program. In this respect, the action of each fund would be made more coherent by allowing the ERDF and the ESF to finance, respectively, residual activities related to physical and human capital. Funding of these activities would be limited and directly linked to the main domains of intervention of each Fund. This would allow both for a simplification and increased effectiveness of programming. The Cohesion Fund and the ERDF will follow a single programming system, where transport and environment infrastructures are 
concerned. The major recipient ministries of EU Funds are mapped in the Table below. Large projects would be adopted by the Commission separately, but managed within the related programs.

\section{Financing of the Common Agricultural Policy (CAP)}

The European Agricultural Rural Development Fund (EARDF) is a new financial instrument for rural development support, approved by the European Council in June 2005 for the programming period 2007-2013. Its aims are to improve the competitiveness of farming and forestry (Axis 1), provide support for the environment and the countryside (Axis 2), promote the diversification of the rural economy and its quality of life (Axis 3), and promote the use of bottom up local development strategies (Axis 4), as presented in the Table below. EARDF is an instrument which brings together all types of programming and financial management and control systems for rural development under a single funding and programming instrument.

The European Agricultural Guidance and Guarantee Fund (EAGGF) finances expenditures related to direct income support and market measures as well as certain veterinary expenditure and information measures relating to the CAP. In effect, through this Fund, the Commission reimburses expenditures incurred (pre-financed) by the Member States.

The table below presents a summary of the financial instruments of the Union and outlines their objectives.

\section{Summary of EU Financial Instruments}

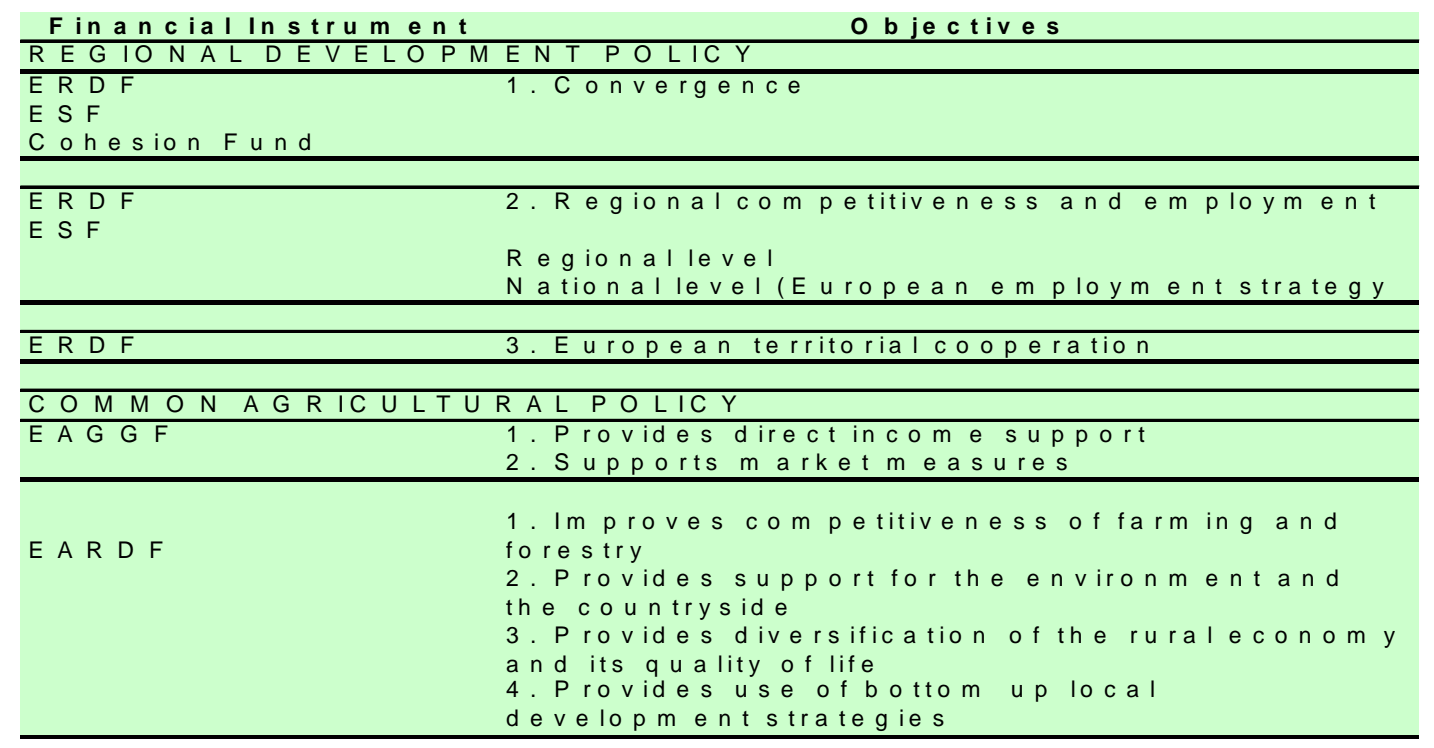

Sources: Council Regulation laying down general provisions on the European Regional Development Fund, the European Social Fund and the Cohesion Fund (COM(2004) 492 final of 14 July 2004), at http://europa.eu.int/eurlex/lex/LexUriServ/site/en/com/2004/com2004_0492en01.pdf. Information on Regional policy: (i) the ERDF is based primarily on Council Regulation (EC) No 1783/1999 of the European Parliament and of the Council of 12 June 1999 on the European Regional Development Fund [Official Journal L 213 of 13.08.1999]; (ii) ESF is based on Regulation (EC) No 1784/1999of the European Parliament and of the Council of 12 July 1999 on the European Social Fund [Official Journal L 213 of 13.08.1999]; (iii) the Cohesion Fund is based on Council Regulation (EC) No 1164/94 of 16 May 1994 establishing a Cohesion Fund [Official Journal L 130 of 25.05.1994]. Amended by: Council Regulation (EC) No 1264/1999 of 21 June 1999 amending Regulation (EC) No 1164/94 [Official Journal L 161 of 26.06.1999]; Council Regulation (EC) No 1265/1999 of 21 June 1999 amending Annex II to Regulation (EC) No 1164/94 [Official Journal L 161 of 26.06.1999]. Information on CAP: (iv) EARDF is based on the European Council's agreement on a Proposal for a Council Decision on Community strategic guidelines for Rural Development (Programming period 2007-2013) 2005/0129 (CNS); (v) Council Regulation (EC) No 1258/1999 of 17 May 1999 on the financing of the common agricultural policy Official Journal L 160 , 26/06/1999 P. 0103 - 0112 
ANNEX II

Table 14 : Estimated appropriations for payments, 2004 prices, $€$ mn.

\begin{tabular}{|c|c|c|c|c|}
\hline & 2007 & 2008 & 2009 & 2007-2009 \\
\hline \multicolumn{5}{|c|}{ Common Agricultural Policy } \\
\hline Market measures & 132 & 129 & 127 & 388 \\
\hline Direct payments & 0 & 198 & 233 & 431 \\
\hline Rural development & 103 & 182 & 197 & 483 \\
\hline Total CAP & 235 & 509 & 557 & 1302 \\
\hline \multicolumn{5}{|l|}{ Structural Actions } \\
\hline Structural Funds & 146 & 256 & 278 & 681 \\
\hline Cohesion Fund & 5 & 45 & 103 & 154 \\
\hline Total Structural Actions & 151 & 302 & 381 & 834 \\
\hline \multicolumn{5}{|l|}{ Internal Policies } \\
\hline Existing policies & 32 & 54 & 73 & 158 \\
\hline Nuclear safety & 0 & 70 & 70 & 140 \\
\hline Institution building $^{1)}$ & 4 & 5 & 5 & 14 \\
\hline Total Internal Policies & 35 & 129 & 148 & 312 \\
\hline \multicolumn{5}{|l|}{ Administration $^{2)}$} \\
\hline Compensation & 122 & 59 & 59 & 240 \\
\hline Total Payments & 544 & 999 & 1145 & 2687 \\
\hline
\end{tabular}

Source: Financial Package for Bulgaria and Romania, indicative allocations 2007-2009 based on Commission Communication of 10 February 2004 and EU Accession Treaty for Bulgaria and Romania of April 2005. Own calculations.

Notes: ${ }^{1)}$ Institution building appropriations for commitments are calculated on the basis of a population key for Bulgaria and Romania. ${ }^{2)}$ No administrative costs are specifically allocated for Bulgaria. Therefore, no commitment and payment appropriations under this heading are included. 
ANNEX III TABLE 15: SUMMARY TABLE OF THE STEPS IN THE CALCULATION OF THE NET BALANCE OF PAYMENTS IMPACT AND THE NET BUDGETARY EFFECT OF EU ACCESSION

\begin{tabular}{|c|c|c|c|c|c|c|c|c|c|c|c|c|c|c|c|c|c|c|}
\hline & \multicolumn{3}{|c|}{ Disbursements } & \multicolumn{3}{|c|}{ Budget revenue } & \multicolumn{3}{|c|}{$\begin{array}{l}\text { Budget expenditure } \\
\text { (without co-financing) }\end{array}$} & \multicolumn{3}{|c|}{ Co-financing } & \multicolumn{3}{|c|}{ Substitution in expenditures } & \multicolumn{3}{|c|}{ Net impact on the budget } \\
\hline & 2007 & 2008 & 2009 & 2007 & 2008 & 2009 & 2007 & 2008 & 2009 & 2007 & 2008 & 2009 & 2007 & 2008 & 2009 & 2007 & 2008 & 2009 \\
\hline \multicolumn{19}{|l|}{ Common Agricultural Policy } \\
\hline Market measures & 140 & 140 & 140 & 140 & 140 & 140 & 140 & 140 & 140 & & & & & & & 0 & 0 & \\
\hline Direct payments & 0 & 214 & 257 & 0 & 214 & 257 & 214 & 257 & 294 & & & & 40 & 44 & 47 & -174 & 1 & 10 \\
\hline Rural development & 110 & 197 & 218 & 110 & 197 & 218 & 110 & 197 & 218 & 27 & 49 & 54 & & & & -27 & -49 & -54 \\
\hline Total CAP & 250 & 551 & 615 & 250 & 551 & 615 & 464 & 594 & 652 & 27 & 49 & 54 & 40 & 44 & 47 & -202 & -49 & -44 \\
\hline \multicolumn{19}{|l|}{ Structural Actions } \\
\hline Structural Funds & 155 & 277 & 307 & 155 & 277 & 307 & 155 & 277 & 307 & 27 & 49 & 54 & & & & -27 & -49 & -54 \\
\hline Cohesion Fund & 6 & 49 & 113 & 6 & 49 & 113 & 6 & 49 & 113 & 1 & 9 & 20 & 6 & 49 & 113 & 5 & 40 & 93 \\
\hline \multirow{2}{*}{\multicolumn{19}{|c|}{ Internal Policies }} \\
\hline & & & & & & & & & & & & & & & & & & \\
\hline Existing policies & 34 & 58 & 80 & 34 & 58 & 80 & 34 & 58 & 80 & & & & & & & 0 & 0 & 0 \\
\hline Nuclear safety & 0 & 76 & 77 & 0 & 76 & 77 & 0 & 76 & 77 & & & & & & & 0 & 0 & 0 \\
\hline Institution building & 4 & 5 & 5 & 4 & 5 & 5 & 4 & 5 & 5 & & & & & & & 0 & 0 & 0 \\
\hline Total Internal Policies & 37 & 140 & 163 & 37 & 140 & 163 & 37 & 140 & 163 & & & & & & & 0 & 0 & 0 \\
\hline \multicolumn{19}{|l|}{ Administration } \\
\hline Compensation & 129 & 64 & 65 & 129 & 64 & 65 & & & & & & & & & & 129 & 64 & 65 \\
\hline Total & 577 & 1081 & 1264 & 577 & 1081 & 1264 & 662 & 1060 & 1236 & 56 & 107 & 129 & 46 & 93 & 161 & -95 & 7 & 60 \\
\hline \begin{tabular}{|l} 
PHARE \\
\end{tabular} & 148 & 120 & 171 & 148 & 120 & \begin{tabular}{|c|}
171 \\
\end{tabular} & 148 & 120 & 171 & 49 & 40 & 57 & & & & -49 & -40 & -57 \\
\hline ISPA & 145 & 132 & 150 & 145 & 132 & 150 & 145 & 132 & 150 & 48 & 44 & 50 & & & & -48 & -44 & -50 \\
\hline SAPARD & 85 & 83 & 0 & 85 & 83 & 0 & 85 & 83 & 0 & 28 & 28 & 0 & & & & -28 & -28 & 0 \\
\hline Pre-accession aid & 379 & 336 & 321 & 379 & 336 & 321 & 379 & 336 & 321 & 126 & 112 & 107 & & & & -126 & -112 & -107 \\
\hline Traditional own resources & 24 & 25 & 28 & -24 & -25 & -28 & & & & & & & & & & -24 & -25 & -28 \\
\hline Resource based on VAT & 36 & 34 & 39 & -36 & -34 & -39 & & & & & & & & & & -36 & -34 & -39 \\
\hline Resource based on GNI & 207 & 229 & 245 & & & & 207 & 229 & 245 & & & & & & & -207 & -229 & -245 \\
\hline Reserve & 1 & 1 & 1 & & & & 1 & 1 & 1 & & & & & & & -1 & -1 & -1 \\
\hline Great Britain Adjustment & 24 & 31 & 31 & & & & 24 & 31 & 31 & & & & & & & -24 & -31 & -31 \\
\hline \begin{tabular}{|l} 
Bulgarian contribution to the EU budget \\
\end{tabular} & 292 & 319 & 343 & -60 & -59 & -67 & 232 & 260 & 276 & & & & & & & -292 & -319 & -343 \\
\hline \begin{tabular}{|l|} 
Contribution to the EIB \\
\end{tabular} & 2 & 2 & 4 & & & & 2 & 2 & 4 & & & & & & & -2 & -2 & -4 \\
\hline \begin{tabular}{|l|} 
Payment to the RFCS \\
\end{tabular} & 0 & 0 & 2 & & & & $\mathbf{0}$ & 0 & 2 & & & & & & & 0 & 0 & -2 \\
\hline \multirow{2}{*}{$\begin{array}{l}\text { Net position with the EU } \\
\% \text { GDP }\end{array}$} & 662 & 1096 & 1237 & & & & & & & & & & & & & & & \\
\hline & $2.6 \%$ & $4.0 \%$ & $4.2 \%$ & & & & & & & & & & & & & & & \\
\hline Net impact on the budget & & & & 896 & 1358 & 1519 & 1275 & $\begin{array}{l}1658 \\
\end{array}$ & \begin{tabular}{|l|l|}
1839 \\
\end{tabular} & 182 & 219 & 236 & 46 & 93 & 161 & -515 & -426 & -396 \\
\hline \% GDP & & & & $3.6 \%$ & $5.0 \%$ & $5.2 \%$ & $5.1 \%$ & $6.1 \%$ & $6.3 \%$ & $0.7 \%$ & $0.8 \%$ & $0.8 \%$ & $0.2 \%$ & $0.3 \%$ & $0.5 \%$ & $-2.1 \%$ & $-1.6 \%$ & $-1.3 \%$ \\
\hline Net impact on the budget, excluding pre-accession funds & & & & 518 & 1022 & 1197 & 896 & 1322 & 1518 & 182 & 219 & 236 & 46 & 93 & 161 & -515 & -426 & -396 \\
\hline \% GDP & & & & $2.1 \%$ & $3.8 \%$ & $4.1 \%$ & $3.6 \%$ & $4.9 \%$ & $5.2 \%$ & $0.7 \%$ & $0.8 \%$ & $0.8 \%$ & $0.2 \%$ & $0.3 \%$ & $0.5 \%$ & $-2.1 \%$ & $-1.6 \%$ & $-1.3 \%$ \\
\hline $\begin{array}{l}\text { Net impact on the budget, excluding (i) direct payments } \\
\text { under CAP, (ii) structural actions and (iii) pre-accession } \\
\text { funds }\end{array}$ & & & & & & & & & & & & 23 & & & 16l & & & -359 \\
\hline$\%$ GDP & & & & $1.4 \%$ & $\begin{array}{r}481 \\
1.8 \% \\
\end{array}$ & $\begin{array}{r}519 \\
1.8 \% \\
\end{array}$ & $2.1 \%$ & $2.7 \%$ & $\begin{array}{r}803 \\
2.7 \% \\
\end{array}$ & $\begin{array}{r}182 \\
0.7 \% \\
\end{array}$ & $\begin{array}{r}219 \\
0.8 \% \\
\end{array}$ & $\begin{array}{r}236 \\
0.8 \% \\
\end{array}$ & $0.2 \%$ & $0.3 \%$ & $\begin{array}{l}101 \\
0.5 \% \\
\end{array}$ & $-\frac{-300}{-1.2 \%}$ & $\frac{-383}{-1.4 \%}$ & $\begin{array}{r}-3.59 \\
-1.2 \% \\
\end{array}$ \\
\hline
\end{tabular}

